\title{
Comparing short term and sustained effects of two strategies to improve nurses' adherence with hand hygiene prescriptions: a cluster randomised trial
}

\author{
A Huis ${ }^{*}, \mathrm{~L}$ Schoonhoven, R Grol, R Donders, M Hulscher, T van Achterberg \\ From International Conference on Prevention \& Infection Control (ICPIC 2011) \\ Geneva, Switzerland. 29 June - 2 July 2011
}

\section{Introduction / objectives}

Improving hand hygiene $(\mathrm{HH})$ compliance is still a major challenge. We compared a literature based 'state of the art' strategy with a 'team directed' strategy, based on social influence and leadership, on their effectiveness on $\mathrm{HH}$ compliance.

\section{Methods}

We undertook a cluster randomised trial with inpatient wards as the unit of randomisation. The 'state of the art' strategy (SAS) included education, reminders, feedback and targeting adequate products and facilities. The 'team directed' strategy (TD) also contained activities based on social influence and leadership, gaining active commitment and initiative of ward management, modelling by informal leaders, and setting norms and targets within the team. Strategies were delivered during a period of 6 months. Measurements took place directly before and after strategy delivery and 6 months later. The effects were evaluated on an intention-to-treat basis by comparing the post-strategyÂ hand hygieneÂ compliance rates with the baseline rates. Multilevel analysis was applied to compensate for the clustered nature of the data by using mixed linear modelling techniques.

\section{Results}

The SAS showed a short-term improvement of 19,6\% and a long term improvement of $23,7 \%$. The improvement for the TD was 33,7\% (short term) and 33.1\% (long term). The difference between TD and SAS showed an Odds Ratio of $1.641(\mathrm{p}<0.001)$ in favour of the 'team directed' strategy.

IQ Healthcare, Radbound University Nijmegen Medical Centre, Nijmegen, Netherlands

\section{Conclusion}

Both the 'state of the art' strategy and the 'team directed' strategy successfully improved hand hygiene compliance, but the 'team directed' strategy showed even better results. The methodology of this 'team directed' strategy can also be used to improve team performance on other patient safety issues.

\section{Disclosure of interest}

None declared.

Published: 29 June 2011

doi:10.1186/1753-6561-5-S6-P119

Cite this article as: Huis et al:: Comparing short term and sustained

effects of two strategies to improve nurses' adherence with hand hygiene prescriptions: a cluster randomised trial. BMC Proceedings 2011 5(Suppl 6): P119.

Submit your next manuscript to BioMed Central and take full advantage of:

- Convenient online submission

- Thorough peer review

- No space constraints or color figure charges

- Immediate publication on acceptance

- Inclusion in PubMed, CAS, Scopus and Google Scholar

- Research which is freely available for redistribution 